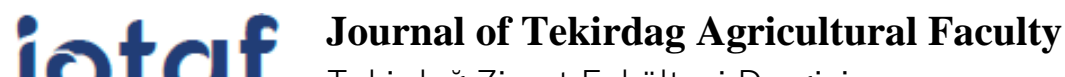 \\ Tekirdağ Ziraat Fakültesi Dergisi
}

Eylül/September 2019, 16(3)

Başvuru/Received: 14/02/19

Kabul/Accepted: 20/08/19

DOI: 10.33462 jotaf.527213

http://dergipark.gov.tr/jotaf

http://jotaf.nku.edu.tr/

ARAŞTIRMA MAKALESİ

RESEARCH ARTICLE

\section{Farklı Bitki Ekstraktlarının Bezelye Bakteriyel Yaprak Yanıklığına (Pseudomonas syringae pv. pisi) Antibakteriyel Etkilerinin Araştırılması}

\author{
Investigation of The Antibacterial Effects of Different Plant Extracts Against Pea Bacterial Leaf \\ Blight Disease Caused by Pseudomonas syringae pv. pisi
}

\section{Mustafa Alparslan UMARUSMAN ${ }^{1-2 * *}$ Yeşim AYSAN $^{1}$ Menșure ÖZGÜVEN $^{2}$}

\section{$\ddot{\mathbf{O} z}$}

Bezelyede bakteriyel yaprak yanıklığı hastalığına neden olan Pseudomonas syringae pv. pisi adlı patojen tohumla taşınır ve dünya genelinde bezelye üretimi yapılan alanlarda önemli bir sorundur. Hastalığın ilk belirtileri kotiledon yapraklarda su emmiş lekeler şeklinde başlar ve ilerleyen aşamada nekrotik lekelere dönüşür. Bu çalışmada, Pseudomonas syringae pv. pisi'ye karşı farklı bitki ekstraktlarının antibakteriyel özelliği araştırılmıştır. Bu amaç doğrultusunda, 34 farklı tıbbi ve aromatik bitkinin sulu ekstraktının in vitro çalışmalarda difüzyon disk yöntemine göre antibakteriyel etkisi araştırılmış ve etkili bulunan bitki ekstraktları tohuma uygulanarak hastalığı baskılama oranı saksı ve tarla denemeleriyle ortaya konmuştur. Petri denemelerinde patojene karşı antibakteriyel etkiye sahip dokuz bitki türü tespit edilmiştir. Farklı dozlar uygulanarak yapılan petri denemelerinde en yüksek antibakteriyel etkiye sahip üç bitki ekstraktıyla (Allium sativum, Cistus creticus ve Syzygium aromaticum) saksı ve arazi denemeleri yapılmıştır. Bu üç bitki ekstraktı saksı denemesinde hastalığı \%17-95, tarla denemesinde \%76-98 oranında baskılamıştır. Çalışmada en etkili tohum uygulamasının Syzygium aromaticum ekstraktı olduğu belirlenmiştir. Syzygium aromaticum ekstraktı uygulaması saksı denemesinde $\% 95$ ve tarla denemesinde $\% 98$ oranda hastalığı engellemiştir. Ayrıca çimlenme oranında \%5 artış da sağladığı belirlenmiştir. Sonuç olarak, bu hastalığın entegre mücadelesinde bitki ekstraklarının tohuma uygulanması başarılı mücadele stratejilerinden biri olarak değerlendirilmiştir.

Anahtar Kelimeler: Pisum sativum L., Pseudomonas syringae pv. pisi, Bitki ekstraktları, Tohum uygulamaları, Organik tarım

\begin{abstract}
Pseudomonas syringae pv. pisi causing pea bacterial leaf blight disease in pea production areas all over the world is a seed-borne pathogen. The initial symptoms of the disease are observed as water-soaked stains on the cotyledon leaves and turn into necrotic stains at a further stage. In this study, the antibacterial properties of plant extracts has tested against Pseudomonas syringae pv. pisi. For this purpose, 34 different medicinal and aromatic plant extracts were investigated in vitro conditions by using diffusion disc method and the degree of inhibition on inoculum was determined through applying plant extracts that found effective to pathogen to seed before planting in the pot and field experiments. In the petri-experiments, nine plant species with antibacterial effects against the pathogen were identified. Three plant extracts (Allium sativum, Cistus creticus and Syzygium aromaticum) which showed the highest antibacterial effect in vitro experiments conducted by applicating of different doses; were investigated in

\footnotetext{
1*Sorumlu Yazar/Corresponding Author: Mustafa Alparslan Umarusman, Çukurova Ünirsitesi, Ziraat Fakültesi, Bitki Koruma Bölümü, Adana, Konya Gıda ve Tarım Üniversitesi, Tarım ve Doğa Bilimleri Fakültesi, Bitkisel Üretim ve Teknolojileri Bölümü, Konya E-mail: mustafa.alp.umarusman@ gmail.com (iD) OrcID: 0000-0001-5762-7216

${ }^{1}$ Yeşim Aysan, Çukurova Ünirsitesi, Ziraat Fakültesi, Bitki Koruma Bölümü, Adana, Konya E-mail: aysanys@ @mail.com

${ }^{2}$ Menşure Özgüven, Konya Gıda ve Tarım Üniversitesi, Tarım ve Doğa Bilimleri Fakültesi, Bitkisel Üretim ve Teknolojileri Bölümü, Konya E-mail: mensure.ozguven@gidatarim.edu.tr (iD) OrcID: 0000-0002-0489-4406

Atıf/Citation: Umarusman, M., Aysan, Y., Özgüven, M. Farklı Bitki Ekstraktlarının Bezelye Bakteriyel Yaprak Yanıklı̆̆ına (Pseudomonas syringae pv. pisi) Antibakteriyel Etkilerinin Araştırılması, Tekirdağ Ziraat Fakültesi Dergisi, 16(3), 297-314

** Bu çalışma ilk yazarın Yüksek Lisans tezinden üretilmiştir.

CBu çalışma Tekirdağ Namık Kemal Üniversitesi tarafından Creative Commons Lisansı (https://creativecommons.org/licenses/by-nc/4.0/) kapsamında yayınlanmıştır. Tekirdağ 2019
} 
terms of their impact on disease outbreak in pot and field experiments. These three plant extracts suppressed the disease in the pot experiment by \%17-95, in the field experiment by \%76-98. In this study, the most effective seed application was determined as Syzygium aromaticum. The extract suppressed the disease by $95 \%$ in pot experiments and $98 \%$ in the field experiments. In addition, Syzygium aromaticum extract had 5\% germination enhancing effect. To conclude, the use of plant extracts as seed application in the integrated management of this disease has been considered as one of the successful management strategies.

Keywords: Pisum sativum L., Pseudomonas syringae pv. pisi, Plant extracts, Seed treatments, Organic agriculture, 


\section{Extendend Summary}

The aim of this study was to determine the plant species with antibacterial properties against Pseudomonas pisi, the rate of disease suppression of plant extracts as seed application and the effect of seed applications on germination ability of seeds. As a first step, the antibacterial effect of 34 different medicinal and aromatic plant extracts against pathogenic bacteria was investigated in the laboratory conditions. 9 different plant extracts were found to be effective against Pseudomonas pisi in in vitro studies. As a result of measuring their zones of inhibition, three plant extracts (A. sativum, C. creticus, S. aromaticum) are found to have the highest antibacterial properties. These extracts have been also examined with pot and field experiments in order to determine their effects on the seed-borne disease. At the end of pot experiments carried out in greenhouses, it was found that when C. creticus extract was applied to pathogen-contaminated pea seeds, the disease was observed in $51 \%$ of the plants. When $A$. sativum extract was applied to them, the disease was observed in $33 \%$ of the plants, and when S. aromaticum extract was applied, the disease was observed in $3 \%$ of the plants. At the end of field experiments carried out to examine disease incidents, it was found that when $C$. creticus extract was applied to pathogen-contaminated pea seeds, the disease was observed in $12 \%$ of the plants and when A. sativum extract was applied, the disease was observed in $8 \%$ of the plants. The disease was observed only in $1 \%$ of the plants on which S. aromaticum extract was applied. Seed applications (physical, chemical, etc.) used in the battle against plant diseases can affect seed germination success by affecting the seed physiology. In the pot experiments carried out to determine the effect of plant extracts on seed germination, healthy seeds were immersed in aqueous extract of $42 \%$ of A. sativum for 30 minutes. After being immersed in aqueous extract, $78 \%$ of healthy seeds germinated. It was seen that this application reduced the germination rate of the seeds by $18 \% .93 \%$ of the seeds, treated with $42 \%$ of C. creticus extract for 30 minutes, were germinated and the rate germination decreased by $2.63 \%$. On the contrary, $100 \%$ of pea seeds treated with $30 \%$ application of S. aromaticum with $42 \%$ aqueous extract of S. aromaticum were germinated and germination rate increased by $5 \%$. Considering the studies conducted, it is concluded that the use of $S$. aromaticum extract as seed application before planting is the most effective and natural method to be applied in the environmentalist struggle with the bacterial leaf blight disease. In this study, it is determined that the application of $S$. aromaticum extract to the seed is an easily applicable method for pea farming because it is a natural and environmental method. In addition, it has a positive effect on seed germination and it is highly efficient against pathogen. The active ingredient of S. aromaticum extract can be produced commercially and can be used in disease control in the future. 
Umarusman \& Aysan \& Özgüven Farklı Bitki Ekstraktlarının Bezelye Bakteriyel Yaprak Yanıklığına (Pseudomonas syringae pv. pisi) Antibakteriyel Etkilerinin Araştırılması Bir baklagil bitkisi olan bezelye (Pisum sativum L.) protein kaynağı olarak yetiştirilmekte ve tüketilmektedir. Genetik çeşitlilik dikkate alındığında Orta Asya, Yakın Doğu, Etiyopya ve Akdeniz havzası bezelyenin orijin merkezidir (Gritton, 1980). Ülkemiz 112.748 da alanda 107.124 ton tane bezelye üretimi gerçekleştirmiştir (TÜIK, 2017). Bölgesel olarak ülkemizde en fazla bezelye üretimi sırasıyla Marmara, Akdeniz ve Ege Bölgelerinde gerçekleşmektedir. Pazar payı oldukça yüksek olan bezelye taze tüketiminin yanında, konserve ve dondurulmuş ürün olarak gıda sanayinin önemli bir ham maddesidir (Ceyhan ve ark, 2005).

Bezelye tarımında verim ve kaliteyi doğrudan etkileyen biyotik ve abiyotik pek çok problem sorun olabilmektedir. Bakteriyel hastalıklar açısından Pseudomonas syringae pv. pisi, Pseudomonas syringae pv. syringae (Ertan, 2012), Pseudomonas viridiflava, Xanthomonas pisi, Xanthomonas axonopodis pv. phaseoli ve Pectobacterium rhapontici adlı bakteriyel etmenlerin bezelyede sorun oluşturduğu görülmektedir Verma (2017).

Ülkemizde ise bezelyede önemli fungal hastalıkların uzun zamandır sorun oluşturduğu bilinmesine (Göre, 2003) rağmen bakteriyel hastalıklar son y1llarda dikkat çekmeye başlamıştır. Pseudomonas syringae pv. pisi'nin neden olduğu Bakteriyel Yaprak Yanıklığı Hastalığı ülkemizde ilk kez 2007 yılında Adana'da Utrillo çeşidi bezelyede saptanmış (Aysan, 2008), ardından 2009 yılında Muğla'nın Fethiye, Aydın'ın Söke, İzmir'in Ödemiş ve Torbalı ilçelerinde Early Sweet, Geneva, Bolero ve Carina bezelye çeşitlerinde (Benlioğlu ve ark, 2010) ve 2014 yilında tekrar Adana'da Carina ve Jof çeşitlerinde (Horuz ve ark, 2015) sorun olduğu bildirilmiştir. Bezelye tarımında önemli bir sorun olan etmen ile ilgili, ülkemizde bezelye 1slah programı kapsamında yapılan çalışmalarda, 30 farklı yerel bezelye hattının Pseudomonas syringae pv. pisi'ye karşı duyarlılığı konusunda çalışmalar yapılmış ve etmene karşı hatların duyarlılık düzeyi ortaya konmuştur (Akça ve ark, 2016).

Pseudomonas syringae pv. pisi ile bulaşık tohumlar, etmenin neden olduğu bakteriyel yanıklık hastalığının en önemli inokulum kaynağıdır. Pseudomonas syringae pv. pisi tohum kökenli bir bitki patojenidir ve tohum kabuğunda yaşamını sürdürür. Patojen bakteri tohumun yüzeyinde veya içinde yaklaşık 3 yıl kadar hayatta kalabilmektedir (Reeves ve ark, 1996; Martin-Sanz ark, 2005; Ertan, 2012). Karantina yönünden Pseudomonas syringae pv. pisi bezelye tohumlarında toleransı sıfır olan bakteriyel bir etmendir. Bu nedenle pek çok ülkenin karantina listesinde yer almaktadır. Etmenle bulaşık tohumların yetiştirilmesi sonucu ilk olarak bitkinin kotiledon yapraklarında hastalık belirtileri görülmektedir. Etmen bitkide hastalık belirtisi oluşturmadan bazı durumlarda latent olarak bitki bünyesinde yaşamını sürdürebilmektedir. Patojen bakteri genel olarak kışı tohumda geçirmekle birlikte bir önceki üretim sezonundan artakalan topraktaki bitki artıklarında da kışı geçirdiği belirtilmiştir (Parry, 1990; Ertan, 2012).

Tohumla taşınan patojenlerin neden olduğu tohum kökenli bakteriyel hastalıklarla mücadelede en etkili yöntemlerden biri üretimde sağlıklı tohum kullanmaktır. Patojenle bulaşık tohumlar imha edilmek yerine çoğu kez tohumdaki patojeni azaltmak veya yok etmek için çeşitli fiziksel (sıcak su, sıcak hava vb) ve kimyasal (bronopol, $\mathrm{NaOCl}$, antibiyotikler vb) tohum uygulamaları kullanılır. Bu uygulamalar tohum yüzeyindeki bakteriyi yok etmede başarılıyken tohumun iç kısmında yani embriyoda bulunan patojenleri yok etmede yeterli olmazlar. Ayrıca bu uygulamaların en önemli dezavantajı tohumun çimlenme gücünü azaltmasıdır (Cantore ve ark, 2009).

Tohumdaki bakteri inokulumuyla mücadelede farklı bir uygulama olarak antibiyotikler incelendiğinde, streptomycin, tetracyclin gibi antibiyotikler tohum kökenli inokulumu yok etmede etkili (Taylor ve Dye, 1975) olmalarına rağmen tarımsal üretimde sürdürülebilir değildir. Rutin antibiyotik kullanımında kısa sürede dirençli 
JOTAF/ Journal of Tekirdag Agricultural Faculty, 2019, 16(3)

bakteri popülasyonlarının ortaya çıkma riski oldukça yüksektir. Bu durum farklı bitki patojeni bakteriler için pek çok araştırmayla ortaya konmuştur (Topal ve ark, 2015). Ayrıca insan sağlığında kullanılan antibiyotiklerle bitki sağlığında kullanılanların aynı olması nedeniyle insan sağlığına olumsuz etkisi, toprak ve tohum mikroflorasına olan olumsuz etkisi, ayrıca ekonomik olmaması göz önüne alındığında ülkemizde olduğu gibi pek çok ülkede de tarımsal alanlarda antibiyotik kullanımı yasaktır (Altundă̆ ve ark, 2007).

Antibiyotiklerin kullanımının yasak olması nedeniyle, son yıllarda doğal antibiyotik olarak adlandırılan tıbbi ve aromatik bitkilerin bünyesinde bulunan biyokimyasalların kullanımı önem kazanmıştır. Tıbbi ve aromatik bitkiler sekonder metabolitler olarak adlandırılan biyokimsal maddelerce zengin olan bitki gruplarıdır. Sekonder metabolitlerin en önemli işlevi, bitkilerin yaşadıkları çevredeki biyotik ve abiyotik stres faktörlerine karşı savunma sistemlerini oluşturmasıdır (Baydar, 2009). Tıbbi ve aromatik bitkilerin yaprakları, tohumları veya diğer dokularından elde edilen ekstraktlar farklı bitkilerin yeşil aksam veya kök sorunlarının çözümünde başarıyla kullanılmaktadır.

Hem geleneksel hem de organik tarımsal üretim sistemlerinde, farklı bitki ekstraktları ve uçucu yağların entegre mücadelenin bir parçası olarak kullanımı son yıllarda oldukça önem kazanmıştır. Bakteriyel bitki hastalıklarının mücadelesinde çeşitli bitki ekstraktlarının tohum dezenfeksiyonu olarak domates (Kotan ve ark, 2007; Talibi ve ark, 2011; Mbega ve ark, 2012; Karabüyük ve Aysan, 2016), biber (Mirik ve Aysan, 2005), fasulye (Satish ve ark, 1998), çeltik (Kagale, 2004) ve bezelyede (Verma ve Agrawal, 2015) kullanımı üzerine pek çok başarılı araştırma bulunmaktadır.

Yapılan tüm bu mücadele çalışmaları göz önüne alındığında ortaya çıkan önem neticesinde, bu çalışma Pseudomonas syringae pv. pisi’ye karşı antibakteriyel özeliğe sahip bitki ekstraktlarının tespit edilmesi, tohum uygulaması olarak kullanıldığında hastalığı baskılama oranının ve uygulamaların tohumların çimlenme yeteneğine etkisinin belirlenmesi amacıyla gerçekleştirilmiştir. Bu doğrultuda çoğu tıbbi ve aromatik olmak üzere 34 farklı sulu bitki ekstraktının Pseudomonas syringae pv. pisi'ye antimikrobiyal etkisi in vitro petri denemeleriyle belirlenmiş, tohum uygulamalarının hastalığı baskılama oranı saksı ve arazi denemeleri ile araştırılmış ve bezelye bakteriyel yaprak yanıklığı hastalığıyla, bitki ekstraktları kullanarak kalıntı problemi olmaksızın, ekonomik ve çevre dostu bir stratejiyle mücadele edilebilme olanakları bu çalışmayla ortaya konmuştur.

\section{Materyal ve Yöntem}

Patojen İzolat. Ç. Ü. Ziraat Fakültesi Bitki Koruma Bölümü Bakteriyoloji laboratuvarı kültür koleksiyonunda bulunan ve Horuz ve ark (2015) tarafından izole edilip tanılanan AK-3r kodlu Pseudomonas syringae pv. pisi izolatı çalışmada kullanılmıştır. Bu izolat 2014 yılında Adana’da bezelye tarlasında yaprak lekelerinden izole edilmiştir.

Bezelye Tohumları. Bu çalışmada Karina çeşidi bezelye tohumları kullanılmıştır. Akça ve ark (2016) tarafından yapılan çalışmada Pseudomonas syringae pv. pisi'nin neden olduğu bezelyede bakteriyel yaprak yanıklığı hastalığına en duyarlı çeşit olarak Karina çeşidinin tespit edilmesi nedeniyle çalışmalarda bu çeşit tercih edilmiştir. 
Umarusman \& Aysan \& Özgüven Farklı Bitki Ekstraktlarının Bezelye Bakteriyel Yaprak Yanıklı̆̆ına (Pseudomonas syringae pv. pisi) Antibakteriyel Etkilerinin Araştırılması

Bitki Ekstraktları. Çalışmada 34 farklı tıbbi ve aromatik bitki türünden elde edilen ekstraktlar kullanılmıştır.

Bunlardan 17 adet bitki türü, Konya Gıda ve Tarım Üniversitesi Bitkisel Üretim ve Teknolojileri Bölümü Tıbbi ve Aromatik Bitkiler Koleksiyon Bahçesinde yetiştirilen tıbbi ve aromatik bitkilerden elde edilmiştir. Ayrıca 6 bitki türü Kadirli iline bağlı Maksutoluğu yaylasından, 7 bitki türü Adana'nın Sarıçam ve Karaisalı ilçeleri florasından toplanmış ve 4 bitki türü de ticari işletmelerden satın alınmıştır.

Çizelge 1. Pseudomonas syringae pv. pisi’ye karşı antibakteriyel etkisi test edilen tıbbi ve aromatik bitki türleri. Table 1. Antibacterial effect of medicinal and aromatic plant species tested against Pseudomonas syringae pv. pisi.

\begin{tabular}{|c|c|c|c|c|}
\hline & Bitki türleri & Yerel Ad 1 & Toplandığı Bölge & Kullanılan Aksam \\
\hline 1 & Aloe vera & Tibbi Sarısabır & Koleksiyon Bahçesi & Yeşil Aksam \\
\hline 2 & Achillea nobilis & Civanperçemi & Kadirli & Yeşil Aksam \\
\hline 3 & Allium sativum & Sarımsak & Ticari İşletme & Soğan \\
\hline 4 & Arum rupicola & Yılan Yastığ & Kadirli & Yeşil Aksam \\
\hline 5 & Capparis spinosa & Gebre Otu & Sarıçam & Çiçek Tomurcuğu \\
\hline 6 & Cistus creticus & Laden & Karaisalı & Yeşil Aksam \\
\hline 7 & Cupressus arizonica & Arizona Servisi & Sarıçam & Yeşil Aksam \\
\hline 8 & Eucalyptus sp. & Okaliptus & Sarıçam & Yeşil Aksam \\
\hline 9 & Ferula communis & Çağşır Otu & Kadirli & Yeşil Aksam \\
\hline 10 & Helichrysum italicum & Ölmez Çiçek & Koleksiyon Bahçesi & Yeşil Aksam \\
\hline 11 & Juglans regia & Ceviz & Kadirli & Meyve Kabuğu \\
\hline 12 & Laurus nobilis & Defne & Kadirli & Yeşil Aksam \\
\hline 13 & Lavandula angustifolia & Lavanta & Koleksiyon Bahçesi & Yeşil Aksam \\
\hline 14 & Lavandula stoechas & Karabaş Otu & Koleksiyon Bahçesi & Yeşil Aksam-Çiçek \\
\hline 15 & Matricaria recutita & Tibbi Papatya & Koleksiyon Bahçesi & Yeşil Aksam \\
\hline 16 & Melissa officinalis & Oğul Otu & Koleksiyon Bahçesi & Yeşil Aksam \\
\hline 17 & Mentha arvensis & Nane & Koleksiyon Bahçesi & Yeşil Aksam \\
\hline 18 & Mentha piperita & Nane & Koleksiyon Bahçesi & Yeşil Aksam \\
\hline 19 & Micromeria fruticosa & Taş Nanesi & Kadirli & Yeşil aksam \\
\hline 20 & Myrtus communis & Yaban Mersini & Sarıçam & Yeşil Aksam \\
\hline 21 & Nerium oleander & Zakkum & Sarıçam & Yeşil Akşam-Çiçek \\
\hline 22 & Nigella sativa & Çörek Otu & Ticari İşletme & Tohum \\
\hline 23 & Origanum onites & İzmir Kekiği & Koleksiyon Bahçesi & Yeşil Aksam \\
\hline 24 & Origanum vulgare & Güvey Otu & Koleksiyon Bahçesi & Yeşil Aksam \\
\hline 25 & Rosmarinus officinalis & Biberiye & Sarıçam & Yeşil Aksam \\
\hline 26 & Salvia hispanica & Chia & Koleksiyon Bahçesi & Yeşil Aksam \\
\hline 27 & Salvia officinalis & Tıbbi Adaçayı & Koleksiyon Bahçesi & Yeşil Aksam \\
\hline 28 & Santolina chamaecyparissus & Lavantin & Koleksiyon Bahçesi & Yeşil Aksam-Çiçek \\
\hline 29 & Satureja hortensis & Sater Otu & Koleksiyon Bahçesi & Yeşil Aksam \\
\hline 30 & Syzygium aromaticum & Baharat Karanfil & Ticari İşletme & Tohum \\
\hline 31 & Thymbra spicata & Karabaş Kekik & Koleksiyon Bahçesi & Yeşil Aksam \\
\hline 32 & Thymus citriodorus & Limon Kekiği & Koleksiyon Bahçesi & Yeşil Aksam \\
\hline 33 & Thymus vulgaris & Adi Kekik & Koleksiyon Bahçesi & Yeşil Aksam \\
\hline 34 & Zingiber officinale & Zencefil & Ticari İşletme & Yumru \\
\hline
\end{tabular}

Besi Yerleri. Çalışmada patojen bakterinin çoğaltılmasında besi yeri olarak King B (KB: Proteose peptone $20.0 \mathrm{~g} \mathrm{lt}^{-1}$; MgSO47H2O $1.5 \mathrm{~g} \mathrm{lt}^{-1}$; tri-potassium phosphate 3-hydrate $1.8 \mathrm{~g} \mathrm{lt}^{-1}$; agar-agar $10.0 \mathrm{~g} \mathrm{lt}^{-1}$ ) ve $+4{ }^{\circ} \mathrm{C}^{\prime} \mathrm{de}$ 
JOTAF/ Journal of Tekirdag Agricultural Faculty, 2019, 16(3)

saklanmasinda Yeast Dextroz Calsiyum Karbonat Agar (YDCA: Yeast Extract $10.0 \mathrm{~g} \mathrm{lt}^{-1}$; dextrose $20.0 \mathrm{~g} \mathrm{lt}^{-1}$; calcium carbonate $20.0 \mathrm{~g} \mathrm{tt}^{-1}$; agar $15.0 \mathrm{~g} \mathrm{lt}^{-1}$ ) besi yerleri kullanılmıştır (Lelliott ve Stead, 1987).

Kullanılan alet ve makinalar. Çalışmada sıcak su banyosu (W. Kronnion), hassas terazi (Sartorius), saf su cihazı (Millipore), magnetik karıştırıcı (Shin Saeng), pH metre (WTW), otoklav (Hirayama), etüv (Nüve), spektrofotometre (Shimadzu), erlen çalkalayıcı (Heidolph), steril kabin (Holten), inkübatör (Memmert), Mcfarland Densitometer (MCF) (Biosan) kullanılmıştır.

\section{Yöntem}

\section{Patojen bakteri süspansiyonun hazırlanması}

Pseudomonas syringae pv. pisi izolatı King B (KB) besi yerinde 48 saat geliştirildikten sonra steril saf suyla MCF:1 ölçüm değerinde bakteri süspansiyonu hazırlanmıştır. Bu süspansiyon 1/10 oranında 5 kez seyreltilmiş ve hazırlanmış seyreltme serilerinin her birinden $100 \mu$ King B besi yeri içeren petrilere bagetle yayılmıştır. Çalışmada patojenin MCF:1 ölçüm değerinde hazırlanmış bakteri populasyonu 3.4x10 ${ }^{8}$ hücre $\mathrm{ml}^{-1}$ olarak belirlenmiştir.

\section{Bitki ekstraktlarının hazırlanması}

Çizelge 1'de görüldüğü gibi tıbbi ve aromatik bitkilerin türüne göre değişmekle birlikte bazılarının tohumu, yeşil aksamı, çiçek tablası veya yumruları kullanılmıştır. Antimikrobiyal etkinin belirlenmesi için hazırlanacak ekstraktlar için önce bitkiler tartılıp havanda öğütüldükten sonra 1/7 oranında saf su eklenmiştir. Uygulanan bu yöntemde Mangamma ve Sreeramulu (1981) yöntemi modifiye edilmiştir. Hazırlanan karışım 30 dakika boyunca $150 \mathrm{rpm} /$ dak hızda dairesel çalkalayıcıya bırakılmıştır. Çalkalama işlemi sonrasında bitki parçaları kaba filtre kağıdı kullanılarak süzülmüş ve geriye kalan sıvı tüplere alınmıştır. Besi yerine eklenmeden önce bitki ekstraktları steril kabin içinde etkili bileşenlerin sıcaklığa duyarlı olma olasılıkları nedeniyle otoklavda steril etmek yerine filtreden (Milipore marka $0.22 \mu \mathrm{m}$ pora sahip) geçirilerek soğuk sterilizasyon yöntemiyle steril edilmiştir. Kullanılan ekstraktlar her deneme öncesi taze olarak hazırlanmıştır.

\section{Farklı bitki ekstraktlarının Pseudomonas syringae pv. pisi'ye antibakteriyel etkisinin araştırılması}

Çalışmada 34 farklı tıbbı ve aromatik bitki ekstraktının bezelye bakteriyel yaprak yanıklığı hastalık etmeni Pseudomonas syringae pv. pisi'ye antibakteriyel etkisi in vitro petri denemeleriyle kağıt difüzyon disk yöntemine göre araştırılmıştır (Mangamma ve Sreeramulu, 1981; Mirik ve Aysan, 2005). King B besi yeri içeren petrilere patojen bakterinin $3.4 \times 10^{8}$ hücre $\mathrm{ml}^{-1}$ popülasyonu içeren süspansiyondan $100 \mu 1$ eklenerek bagetle yayılmıştır. Petriler kuruduktan (yaklaşık 1 saat) sonra, $5 \mathrm{~mm}$ çapında yuvarlak Oxoid blank diskler birbirinden eşit uzaklıkta olacak şekilde petrilerin üç ayrı noktasına yerleştirilmiştir. Farklı bitkilerden elde edilen steril bitki ekstraktlarının 10,15 ve $20 \mu l$ konsantrasyonları steril diskler üzerine emdirilmiştir. Negatif kontrol olarak steril su, pozitif kontrol olarak streptomycin antibiyotiği içeren Oxoid diskler $(25 \mu \mathrm{g})$ kullanılmıştır. Çalışma üç tekrarlı olarak yapılmıştır. Petriler $25^{\circ} \mathrm{C}$ 'de 48 saat inkübe edilmiş ve diskler etrafında oluşan inhibisyon (engelleme) zonları ölçülerek (cm) kaydedilmiştir.

\section{Bitki ekstraktlarının tohum uygulaması olarak bakteriyel yaprak yanıklığı hastalığına etkisi}

Bir önceki aşama olan petri denemelerinde Pseudomonas syringae pv. pisi'ye antibakteriyel etkisi saptanan Allium sativum (Sarımsak), Cistus creticus (Laden) ve Syzygium aromaticum (Baharat Karanfil) bitki ekstraktları 
Umarusman \& Aysan \& Özgüven Farklı Bitki Ekstraktlarının Bezelye Bakteriyel Yaprak Yanıklığına (Pseudomonas syringae pv. pisi) Antibakteriyel Etkilerinin Araştırılması çalışmanın bu aşamasında kullanılmıştır. Suni olarak Pseudomonas syringae pv. pisi ile bulaştırılmış bezelye tohumuna bu üç bitki ekstraktı uygulanarak tohum kökenli inokulumdan kaynaklı hastalığı engelleme oranları saksı ve tarla denemeleriyle araştırılmıştır. Arazi ve saksı denemelerinde kullanılacak patojen bakteri, King B (KB) besi yerinde 48 saat geliştirildikten sonra steril saf suyla MCF:1 ölçüm değerinde hazırlanan bakteri süspansiyonundan hazırlanmış ve yaklaşık $3.4 \times 10^{8}$ hücre $\mathrm{ml}^{-1}$ patojen bakteri popülasyonu denemelerde kullanılmıştır. Bitki ekstraktları ise ekstraktsiyon için kullanılacak bitki kısımları tartılıp havanda öğütüldükten sonra 1/7 oranında saf su eklenerek hazırlanmıştır. Hazırlanan karışım 30 dakika boyunca $150 \mathrm{rpm} \mathrm{dak}^{-1}$ hızda dairesel çalkalayıcıya bırakılmışırı. Çalkalama işlemi sonrasında bitki parçaları kaba filtre kağıdı kullanılarak süzülmüş ve geriye kalan sıvı tüplere alınarak kullanılmıştır (Mirik ve Aysan, 2005).

Bezelye tohumlarına patojenin bulaştırılması. Patojen bakterilerin tohumlara daha iyi yapışmasını sağlamak amacıyla, 5 gr karboksimetil selülaz (CMC) 1 litre saf su ile magnetik karıştıııcıda ısıtılarak \%0.5 lik solüsyon hazırlanmıştır. Saf su içinde yeterince çözülen CMC soğutulduktan sonra MFC:1 ölçüm değerinde bakteri popülasyonu oluşuncaya kadar 48 saatlik saf bakteri kolonisinden solüsyona eklenmiştir. Hazırlanan süspansiyona bezelye tohumları eklenerek 30 dakika süreyle $150 \mathrm{rpm}$ dak $^{-1}$ hızda oda sıcaklığında çalkalanmaya bırakılmıştır. Çalkalanma işlemi bittikten sonra bakteri solüsyonundan süzülen tohumlar kaba filtre kağıdı üzerinde nemi uçana kadar bekletilmiştir. Negatif kontrol olarak bezelye tohumları aynı şekilde steril saf suyla, pozitif kontrol olarak tohumlar sadece patojenle bulaştırılmıştır.

Patojenle bulaşık tohumlara bitki ekstraktlarının uygulanması. Patojenle suni olarak bulaştırılan bezelye tohumları nemi uçuncaya kadar bekletilmiş (yaklaşık 1 saat) ve sonrasında erlen mayerlerde taze olarak hazırlanan \%42'lik sulu bitki ekstrakları ile 30 dakika süreyle $150 \mathrm{rpm} \mathrm{dak}^{-1}$ hızda oda sıcaklığında çalkalanmaya bırakılmıştır. Çalkalama işlemi bittikten sonra süzülen tohumlar 20x20 cm ebatlarında üzeri tülbentle çevrilmiş tahta çerçevelere yayılarak oda koşullarında nemi uçana kadar bekletilmiştir.

Saksı denemesi. Çukurova Üniversitesi Ziraat Fakültesi Bitki Koruma Bölümü Araştırma ve Deneme Parselinde bulunan cam serada 21 Şubat-1 Nisan 2018 tarihleri arasında yapılmıştır. Tesadüf parselleri deneme desenine göre kurulan saksı denemesinde, uygulama görmüş bezelye tohumları 1:1 oranda toprak ve ahır gübresi karışımı ile doldurulmuş 3 litrelik saksılara ekilmişsir. Her uygulama 4 tekrar ve her tekrarda 10 tohum kullanılmıştır. Uygulama görmüş bezelye tohumları aynı gün içinde saksılara ekimi yapılmıştır. Çalışmada pozitif kontrol olarak Pseudomonas syringae pv. pisi ile bulaştırılmış ve hiçbir uygulama yapılmamış Karina çeşidi bezelye tohumları kullanılmıştır. Negatif kontrol olarak sağlıklı tohumlar saf suya daldırılmıştır.

Tarla denemesi. Adana ilinin Karaisalı ilçesinde bir üretici tarlasında 23 Şubat -1 Nisan 2018 tarihleri arasında yürütülmüş̧ür. Tesadüf blokları deneme desenine göre kurulan tarla denemesinde, uygulama görmüş bezelye tohumları $1.5 \times 1.4 \mathrm{~m}$ ölçülerindeki parsellere $10 \mathrm{~cm}$ sıra üzeri $50 \mathrm{~cm}$ sıra arası mesafede ekilmiştir. Her uygulama 5 tekrar ve her tekrarda 60 tohum kullanılmıştır. Tohum uygulamalarıyla dormansisi kırılan bezelye tohumlarının çimlenme yüzdesinde olumsuz bir durum oluşmaması için uygulama yapılan tohumların aynı gün içerisinde ekimi tamamlanmıştır. Çalışmada pozitif kontrol olarak Pseudomonas syringae pv. pisi ile bulaştırılmış ve hiçbir uygulama yapılmamış bezelye tohumları kullanılmıştır. Negatif kontrol olarak sağlıklı tohumlar saf suya daldırılmıştır.

\section{Denemelerin değerlendirilmesi}


JOTAF/ Journal of Tekirdag Agricultural Faculty, 2019, 16(3)

Bitki ekstraktlarıyla uygulama görmüş patojenle bulaşık tohumlar, saksılara ve tarlaya ekildikten sonra haftalık kontrol edilerek ilk çıkan birleşik yapraklardaki ıslak lekeler veya nekrotik alanların varlığı takip edilmiştir. Pozitif kontrol bitkilerinin tamamına yakınında hastalık belirtileri gözlendiği zaman (ekimden yaklaşık 4 hafta sonra) denemeler sonlandırılmıştır. Denemelerde her tekrardaki, toplam bitki sayısı ve hastalıklı bitki sayısı kaydedilip hastalık oranı hesaplanarak uygulamaların hastalık oranına etkisi Abbott formülüne (\% etki: (kontroluygulama/kontrol) x100) göre hesaplanmıştır. Daha sonra ortalama hastalık oranı hesaplanmış ve bu rakamların açı değerleri alınarak ANOVA İstatistik programında Duncan çoklu karşılaştırma testine $(\mathrm{P} \leq 0,05)$ göre, farklı bitki ekstraktlarının bezelye yaprak yanıklığı hastalığına etkisi istastistiki olarak değerlendirilmiştir.

Her bir uygulamadaki hastalıklı bitkilerden örnek alınarak klasik bakteriyolojik yöntemlerle izolasyon yapılmış ve elde edilen bakteri izolatlarının tütünde aşırı duyarlılık reaksiyonları (Lelliott ve Stead, 1987) belirlenmiştir. Gözlenen hastalık belirtilerinin sorumlusunun Pseudomonas syringae pv. pisi olup olmadığ teyit edilmiştir.

\section{Tohum uygulamalarının çimlenmeye etkisi}

Deneme, Çukurova Üniversitesi Ziraat Fakültesi Bitki Koruma Bölümü Araştırma ve Deneme Parselinde bulunan cam serada 21 Şubat-1 Nisan 2018 tarihleri arasında yapılmıştır. Sağlıklı bezelye tohumlarına Allium sativum, Cistus creticus ve Syzygium aromaticum bitki ekstraktları uygulanarak tesadüf parselleri deneme desenine göre kurulan saksı denemeleriyle tohum uygulamalarının çimlenme üzerindeki etkileri araştırılmıştır. Negatif kontrol olarak saf su ile uygulama görmüş tohumlar kullanılmıştır.

\section{Bulgular}

\section{Pseudomonas syringae pv. pisi'ye antibakteriyel etkinin araştırılması}

Bezelye bakteriyel yaprak yanıklı̆̆ etmeni Pseudomonas syringae pv. pisi’ye $\left(3.4 \times 10^{8}\right.$ hücre $\mathrm{ml}^{-1}$ popülasyonu) üç farklı dozda hazırlanan 34 tıbbı ve aromatik bitki ekstraktının antibakteriyel etkisinin araştırıldığı in vitro petri denemelerinde, dokuz bitki ekstraktının etkili olduğu saptanmıştır. En düşük doz olan $10 \mu 1$ konsantrasyondaki Allium sativum, Cistus creticus ve Syzygium aromaticum ekstraktları petride sirasıyla ortalama 3, 1 ve 1 mm inhibisyon zonu oluşturmuştur. Bitki ekstraktı dozu $15 \mu$ l'ye artırıldığında altı bitki ekstraktı (Allium sativum, Aloe vera, Cistus creticus, Nigella sativa, Rosmarinus officinalis ve Syzygium aromaticum) 1 ile $6 \mathrm{~mm}$ arasında inhibisyon zonu oluşturarak Pseudomonas syringae pv. pisi’ye antibakteriyel etki göstermiştir. Bitki ekstraktı konsantrasyonu $20 \mu$ l'ye artırıldığında dokuz bitki ekstraktı (Allium sativum, Aloe vera, Cistus creticus, Matricaria recutita, Nigella sativa, Origanum onites, Rosmarinus officinalis, Syzygium aromaticum, Zingiber officinale) 1 ile $8 \mathrm{~mm}$ arasında inhibisyon zonu oluşturarak patojen bakterinin gelişimini baskı altına almıştır. Bitki ekstraktı dozu arttığında patojen bakteriyi engellemede artışın olduğu kaydedilmiştir. Örneğin Allium sativum ekstraktının dozu arttığında inhibisyon zonu sırasıyla 3, 6 ve 8 mm, Cistus creticus ekstraktının dozu arttığında 1, 2 ve $4 \mathrm{~mm}$ ve Syzygium aromaticum ekstraktının dozu arttığında ise 1, 1 ve $3 \mathrm{~mm}$ olarak kaydedilmiştir. Pozitif kontrol olarak kullanılan streptomycin antibiyotiği içeren Oxoid diskler $(25 \mu \mathrm{g})$ 'in oluşturduğu inhibisyon zonları 17 mm olarak kaydedilmiştir. 
Umarusman \& Aysan \& Özgüven Farklı Bitki Ekstraktlarının Bezelye Bakteriyel Yaprak Yanıklığına (Pseudomonas syringae pv. pisi) Antibakteriyel Etkilerinin Araştırılması Bitki ekstraktlarının tohum uygulaması olarak bakteriyel yaprak yanıklığı hastalığına etkisi

Saksı Denemesi. 21 Şubat 2018'de saksılara ekilen tohumlar 1 Mart 2018 tarihinde çimlenmiş ve pozitif kontrolde hastalık belirtileri 16 Mart 2018 tarihinde gözlenmeye başlanmış ve değerlendirme 1 Nisan 2018'de yapılmıştır. Pseudomonas syringae pv. pisi’nin neden olduğu bezelye bakteriyel yaprak yanıklığı hastalı̆̆ından dolayı ilk çıkan birleşik yapraklarda düzensiz su emmiş lekeler tipik hastalık belirtisi olarak kaydedilmiştir. İlerleyen zaman içinde bu lekeler kahverengiye dönüşerek nekrotik alanlar meydana getirmiştir. Suni olarak Pseudomonas syringae pv. pisi ile bulaştırılmış herhangi bir tohum uygulamasının yapılmadığı pozitif kontroldeki bitkilerin ortalama \%61.1'inde hastalık belirlenmiştir (Çizelge 2). Patojenle bulaşık bezelye tohumlarına Cistus creticus ekstraktı uygulandığında bitkilerin \%50.6'sında, Allium sativum ekstraktı uygulandı̆̆ında \%32.5'inde ve Syzygium aromaticum ekstraktı uygulandı̆̆ında \%2.78'inde hastalık saptanmıştır.

Çizelge 2. Bitki ekstraktlarının tohum uygulaması olarak bakteriyel yaprak yanıklığı hastalığına etkisi (saksı denemesi).

Table 2. The effect of plant extracts on bacterial leaf blight disease as a seed application (pot experiment).

\begin{tabular}{lcc} 
Uygulamalar & Hastalık Oranı (\%) & Etki \% \\
\hline Negatif Kontrol & 0.00 & - \\
\hline Pozitif Kontrol & $61.1 \mathbf{a}^{*}$ & - \\
\hline Allium sativum & $32.5 \pm 1.15 \mathbf{a}$ & 46.8 \\
\hline Cistus creticus & $50.6 \pm 0.47 \mathbf{a}$ & 17.3 \\
\hline Syzygium aromaticum & $2.78 \pm 0.82 \mathbf{b}$ & 95.4 \\
\hline
\end{tabular}

*: Aynı harfler aynı istatistiki grubu gösterir.

Tarla Denemesi. Adana ilinin Karaisalı ilçesinde bir üretici tarlasında 23 Şubat 2018'de ekilen tohumlar 10 Mart 2018 tarihinde çimlenmiş ve pozitif kontrolde hastalık belirtileri 17 Mart 2018 tarihinde gözlenmeye başlanmış ve son değerlendirme 1 Nisan 2018'de yapılmıştır. Bitkilerde Pseudomonas syringae pv. pisi'nin neden olduğu bezelye bakteriyel yaprak yanıklık hastalığının tipik belirtisi olan su emmiş lekeler ve kahverengi nekrotik alanlar gözlenmiştir. Çizelge 3'de görüldüğü gibi sadece Pseudomonas syringae pv. pisi ile bulaştırılmış pozitif kontroldeki bitkilerin ortalama \%49.2'sinde hastalık saptanmıştır. Patojenle bulaşık bezelye tohumlarına Cistus creticus ekstraktı uygulandığında bitkilerin \%11.6'sında, Allium sativum ekstraktı uygulandığında \%7.58'inde hastalık saptanmıştır. Syzygium aromaticum ekstraktı uygulanan tohumlardan gelişen bitkilerde \%1 oranda hastalık tespit edilmiştir.

Çizelge 3. Bitki ekstraktlarının tohum uygulaması olarak bakteriyel yaprak yanıklığı hastalığına etkisi (tarla denemesi).

Table 3. The effect of plant extracts on bacterial leaf blight disease as a seed application (field experiment).

\begin{tabular}{lcc} 
Uygulamalar & Ortalama Hastalık Oranı (\%) & Etki \% \\
\hline Negatif Kontrol & 0.00 & - \\
\hline Pozitif Kontrol & $49.2 \mathbf{a}$ & 84.6 \\
\hline Allium sativum & $7.58 \pm 0.47 \mathbf{~ b}$ & 76.4 \\
\hline Cistus creticus & $11.6 \pm 0.26 \mathbf{b}$ & 97.9 \\
\hline Syzygium aromaticum & $1.00 \pm 0.44 \mathbf{c}$ & - \\
\hline
\end{tabular}

*: Aynı harfler aynı istatistiki grubu gösterir. 
Çizelge 3'de görüldüğ̈̈ gibi, Syzygium aromaticum ekstraktı tohum kökenli inokulumdan kaynaklı hastalığı çok büyük oranda engellemiştir. Cistus creticus ve Allium sativum ekstraktları tohum uygulaması olarak kullanıldığginda hastalığg sırasıyla \%76.4 ve \%84.6 oranında baskılamıştır. İstatistiki olarak incelendiğinde tüm uygulamalar pozitif kontrolden farklı grupta yer alarak etkili uygulamalar olarak değerlendirilmiştir. Tohuma Cistus creticus ve Allium sativum ekstraktı uygulamaları aynı grupta yer alan etkili uygulamalarken Syzygium aromaticum ekstraktı uygulaması tek başına bir grup oluşturmuştur. Saksı denemesinde olduğu gibi tarla denemesinde de en başarılı tohum uygulamasının Syzygium aromaticum olduğu saptanmıştır.

Saksı ve tarla denemelerinde hastalığın tespit edildiği her parselden örnek alınarak bakteriyolojik yönden yapılan incelemelerde patojen bakteri geri izole edilmiş, tütün de aşırı duyarlılık reaksiyonun pozitif olduğu belirlenmiş ve hastalık belirtilerinin sorumlusunun Pseudomonas syringae pv. pisi olduğu kanıtlanmıştır.

\section{Tohum uygulamalarının çimlenmeye etkisi}

Çizelge 4'de görüldüğü gibi hiçbir uygulamanın yapılmadığı Karina çeşidi bezelye tohumlarının \%95'i saksıda çimlenmiştir. Sağlıklı tohumlar Allium sativum'un sulu ekstraktına daldırıldığında \% 77.5'i çimlenmiştir. Bu uygulama tohumların çimlenme oranını \%18.4 düzeyinde azaltmıştır. Cistus creticus ekstraktıyla uygulama görmüş tohumların \%92.5'i çimlenmiş ve çimlenme \%2.63 oranında azalmıştır. Bunların aksine sağlıklı tohumlara Syzygium aromaticum'un sulu ekstraktı tohumlara uygulandığında tohumların çimlenme oranında artış saptanmış ve çimlenme \%5.26 oranında artmıştır. İstatistiki olarak incelendiğinde sadece tohuma Allium sativum ekstraktı uygulaması farklı bir grupta yer almış ve bezelye tohumlarının çimlenme düzeyini azaltan başarısız uygulama olarak değerlendirilmiştir. Tohuma Cistus creticus ve Syzygium aromaticum ekstraktı uygulandığında çimlenme düzeyi kontrolle aynı istatistiki grupta yer alarak tohumun çimlenmesine herhangi bir olumsuz etki yapmadığı kanıtlanmıştır.

Çizelge 4. Bitki ekstraktlarının bezelye tohumlarının çimlenmesine etkisi (saksı denemesi).

Table 4. Effect of plant extracts on germination of pea seeds (pot experiment).

\begin{tabular}{llc}
\hline Uygulamalar & Ortalama Çimlenme Oranı (\%) & Fark (\%) \\
\hline Negatif Kontrol & $95.0 \mathbf{a}$ & - \\
\hline Allium sativum & $77.5 \pm 0.62 \mathbf{b}$ & -18.4 \\
\hline Cistus creticus & $92.5 \pm 0.00 \mathbf{a}$ & -2.63 \\
\hline Syzygium aromaticum & $100 \pm 0.48 \mathbf{a}$ & +5.26 \\
\hline
\end{tabular}

*: Aynı harfler aynı istatistiki grubu gösterir.

Tohum uygulaması olarak Syzygium aromaticum'un sulu ekstraktı kullanıldığında hastalık başarılı bir şekilde baskı altına alınırken çimlenmede de artış sağlanmıştır. Bu denemede de Syzygium aromaticum ekstraktı tekrar en başarılı uygulama olarak belirlenmiştir.

\section{Tartışma}

Tarımın sürdürülebilir kılınması, ekolojik dengenin korunmasıyla mümkündür. Tarımsal üretimde verim ve kaliteyi etkileyen çok faktörlü bitki sağlığı problemleri bulunmaktadır. Biyotik ve abiyotik sorunlarla mücadele kullanılan tarım ilaçları, tarımda hem karlılığın azalmasına hem de çevre kirliliğine neden olarak ekolojik dengenin 
Umarusman \& Aysan \& Özgüven Farklı Bitki Ekstraktlarının Bezelye Bakteriyel Yaprak Yanıklı̆̆ına (Pseudomonas syringae pv. pisi) Antibakteriyel Etkilerinin Araştırılması bozulmasına yol açmaktadır. Bu sebeple tarımsal üretimdeki patolojik ve diğer etmenlere karşı çevreci mücadelenin önemi her geçen gün artmaktadır.

T1bbi ve aromatik bitkiler böcek, akar, nematod, bakteri, fungus ve virüslerin mücadelesinde kullanılan çevre dostu ve yeni bir alternatiftir. Tıbbi ve aromatik bitkilerin yaprakları veya tohumlarından elde edilen ekstraktlar farklı bitkilerin yeşil aksam veya kök sorunlarının çözümünde başarıyla kullanılmaktadır. Zengin bitki florasına sahip ülkelerde bu bitkilerin kolay temin edilmesi, uygulama kolaylığı ve ucuz olması nedeniyle yaygın kullanımları alanları bulunmaktadır. Özellikle az gelişmiş veya gelişmekte olan ülkelerde çok eski tarihlerden beri yöresel bitkilerin hem bitki hastalıklarının hem de insan hastalıklarının tedavisinde yaygın kullanıldığını gösteren kayıtlar mevcuttur (Gahukar, 2012). Bitkiler arasında çeşitli mikroorganizmalara toksik etki gösteren çok sayıda bitki türü vardır. Evrim sürecinde bu bitkiler çevresel faktörlere, hastalık ve zararlılara karşı koymak için savunma mekanizması olarak bünyelerinde çeşitli toksik maddeleri biriktirmişlerdir. Günümüzde bilim insanları mikroorganizmalara toksik madde içeren bu doğal bitki türlerini bulup kullanma potansiyellerini araştırmaktadırlar (Slusarenko ve ark, 2008).

Bitki bakteriyel hastalıklarının mücadelesinde, doğal bakterisitler olarak değerlendirilen çeşitli tıbbi ve aromatik bitkilerden elde edilen ekstraktların ve/veya onların uçucu yağlarının etken maddesi tarımda yeni kimyasalların ortaya çıkışına da olanak sağlamıştır. Bu antimikrobiyal maddeler direkt olarak hastalık mücadelesinde biyopestisit olarak kullanılabileceği gibi bunların etken maddesi sentetik olarak üretilerek yeni pestisitlerin piyasaya sürülmesine de katkı sağlamaktadır (Bajpai ve ark, 2011). Gün geçtikçe sayısında farklılık olsa da 1981-2006 yılları arasında kullanılan 109 yeni antibiyotiğin \%69'u doğal bitkisel ürünlerden \%21'i funguslardan elde edilmiştir. Bitkilerden elde edilen antimikrobiyal bileşikler, bakteriyel hastalıkların mücadelesinde antibiyotiklerin (streptomisin, oksitetrasiklin, kloramfenikol ve rifampisin) ve bakırın alternatifi olarak değerlendirilmektedir (Savoia, 2011).

Bitki ekstraktlarından elde edilen bu antibakteriyel ürünler, pek çok gram negatif ve gram pozitif bakterinin birbiriyle iletişim kurma mekanizması olan "quorum-sensing" mekanizmasını engelleyerek ve bakterilerin topluluk oluşturma yetenekleri olan "biofilm" oluşumunu engelleyerek bakteriyel enfeksiyonu azaltırlar. Bitki ekstraktlarının yapısındaki flavonoidler, alkoloidler, terpenler, fenolikler, polifenoller ve tat-koku veren kumarinler bu mekanizmalarla bakterilere etki ederler. Örneğin bakterilerin biofilm oluşumunu engellemede sülfürce zengin kokulu Allium (Savoia, 2011) ve Cistus türleri (Vieira ve ark, 2017) bunlara örnektir. Çin'de yetiştirilen veya endemik olan pek çok tıbbi ve aromatik bitkilerin antibiofilm özellikleri kanıtlanmıştır. Ayrıca ülkemizde de pek çok endemik türü bulunan kekik türlerinin içerdiği thymol de bakterilerin birbiriyle iletişim kurmasını ve topluluk oluşturmasını engeller. Böylece bakterilerin hastalık yapma yetenekleri azalır veya tamamen yok olur (Kotan ve ark, 2009). Özellikle ilaçlara direnç kazanmış bakterilerle mücadelede bitki ekstraktları ve onların uçucu yağlarının kullanımı hastalıklarla mücadelede yeni stratejilerdir (El-Astal, 2004). Doğal antibiyotik olarak bilinen bitki ekstraktlarının etken maddelerine şimdiye kadar herhangi bir direnç probleminin de rapor edilmemesi bunların diğer bir olumlu özelliğidir.

Bakırlı bileşiklerin bitkideki fitotoksite problemi, toprakta ağır metal olarak birikme özelliği, çok sık aralıklarla bitkiye püskürtülme zorunluluğu ve Avrupa Birliğinin 2002 yılında bakır tuzlarının kullanımını sınırlandırması nedeniyle Avrupa'da bakteriyel hastalıkların mücadelesinde alternatif uygulamalar araştırılmaya başlanmıştır (Balestra ve ark, 2009; Cantore ve ark, 2009). Halen bakırlı preparatların alternatifi olacak ticari 
JOTAF/ Journal of Tekirdag Agricultural Faculty, 2019, 16(3)

ürünler piyasada bulunmamaktadır. Avrupa Birliğinin (Council Regulation 2092/91) yasaları gereği organik üretimlerde kullanılan tohum ve fide de organik üretilmiş olmalıdır. Tohum kökenli hastalıklar ve tohum hijyeni için kabul edilebilir tohum uygulamaları kullanılmalıdır. Ticari tohum firmaları çimlenme oranını artırmak ve tohumların aynı zamanda çimlenmesini sağlamak için “priming” denilen yöntemi kullanırlar. Tohumlar bilinen bir sıvıya batırılır ve dormansisi kırılmaksızın tekrar kurutulurlar. Her firmanın kullandı̆̆ı priming protokolü gizli bilgidir. Bu bağlamda priming protokolüne bitki ekstraktlarını dahil etmek hem hastalık etmenleri hem de çimlenme başarısı için uygundur (Slusarenko ve ark, 2008). Tohumlardaki bakteri popülasyonunu yok etmek için sicak su, $\mathrm{NaOCl}$ (hipo), organik ve inorganik asitler gibi farklı kimyasallar kullanılsa da bu uygulamalar tohum yüzeyindeki bakteriyi öldürmede başarılıyken tohumun iç kısmında yani embriyoda bulunan bakterileri öldürmede yeterli olamazlar. Ayrıca bu uygulamaların en önemli dezavantajı tohumun çimlenme gücünü azaltmasıdır (Cantore ve ark, 2009). Bu nedenlerle bitki ekstraktları veya onların uçucu yağları üzerine pek çok araştırma yapılmaktadır.

Tıbbi ve aromatik bitkiler içerisinde bakteriyel etmenlere etkisi en çok araştırılan ve hakkında en fazla makale yazılan bitki türlerinden biri de Allium sativum (sarımsak)'dur. Yapılan araştırmalarda sarımsağın ana bileşenlerinin allicin, diallyl sulfide, thiosulfinale, diallyl cysteine sulfoxide olduğu belirlenmiştir (Gahukar, 2012). Sarımsak en az 33 farklı sülfürlü madde, pek çok enzim, 17 aminoasit ve selenyum gibi mineralleri de içerir (ElAstal, 2004). Sarımsağın dokuları parçalandığında alliin-lyase enziminin aktivitesi sonucu sarımsağın etkili maddesi olan allicin (diallyl thiosulfinale) açığa çıkar ve kendine has sülfürlü kokusu yayılır. Bir baş sarımsağı yaklaşık 50 gram, tek bir diş sarımsağı yaklaşık 5 gram kabul edersek bir kilo (yaklaşık 20 baş) sarımsakta 2 gram allicin bulunur. Taze sarımsağın antimikrobiyal etkisi daha güçlüdür. Hobi bahçeleri gibi küçük alanlarda hazırlanıp hemen kullanılabilir. Taze hazırlanmış sarımsak ekstraktı $4^{\circ} \mathrm{C}$ 'de 10 gün özelliğini korurken $80^{\circ} \mathrm{C}$ 'de 10 dakikada tüm özelliğini kaybeder. Laboratuvar çalışmalarında otoklav edildiğinde veya beş dakika kaynatıldığında antibakteriyel etki tamamen ortadan kalkar. Bu nedenle sıcaktan korumak önemlidir. Buna karşın $-10^{\circ} \mathrm{C}$ 'de antibakteriyel etkisini kaybetmeden üç ay sarımsak suyu olarak saklanabilir (El-Astal, 2004). Taze sarımsak ekstraktı, insan ve bitki patojeni bakterilere karşı son derece etkili antimikrobiyal özelliğe sahiptir. Sarımsak ekstraktı in vitro koşullarda bitki patojeni Rhizobium radiobacter, Pectobacterium carotovorum, Pseudomonas syringae pv. maculicola, Pseudomonas savastanoi pv. phaseolicola, Pseudomonas syringae pv. tomato, Xanthomonas campestris pv. campestris'in petride gelişimini engelleme yeteneğindedir. In vitro koşullarda insan patojeni Esherichia coli'ye karşı ampisilin ve kanamisin antibiyotiklerinden 10-12 kat daha güçlü etkiliye sahiptir (Curtis ve ark, 2004). Sarımsak organik üretimlerde sentetik fungisitlerin alternatifi olarak düşünülebilir. Sarımsak havuç tohumlarında bulunan tohum kökenli Alternaria spp.'lerin, domates ve patateste mildiyö hastalığına neden olan Phytopthora infestans'ın mücadelesinde de kullanılır. Sarımsak fungal etmenleri baskı altına almasının yanı sıra bitkide salisilik asit birikimine neden olarak bitkinin dayanıklık mekanizmasını uyarır. Bitki yapraklarına püskürtüldüğünde sadece patojenleri yok etmez aynı zamanda konukçu bitkide sistemik dayanıklılığı da uyarır (Curtis ve ark, 2004; Slusarenko ve ark, 2008). Ayrıca kuraklık stresine karşı bitkiyi koruma özelliğindedir. Bu bitkilerin yaygın kullanıldığ (soğan) ve Allium sativum (sarımsak)'un fungal etmenlerden Fusarium oxysporium, Alternaria alternata, Colletetrichum gloeosporiodes ve Tetranycus urticae adlı akarın mücadelesinde başarıyla kullanıldığ bilinmektedir (Gahukar, 2012). Bizim çalışmamızda da in vitro denemelerde en yüksek antimikrobiyal etkinlik 
Umarusman \& Aysan \& Özgüven Farklı Bitki Ekstraktlarının Bezelye Bakteriyel Yaprak Yanıklığına (Pseudomonas syringae pv. pisi) Antibakteriyel Etkilerinin Araştırılması sarımsak ekstraktında saptanmıştır. Fakat saksı ve arazi denemelerindeki sarımsak uygulaması diğer etkili bulunan Cistus creticus ve Syzygium aromaticum uygulamalarından daha az başarı sağlamıştır. Bunun nedeni kültür bitkisinin doğal koşullar altında yetiştirilirken çevresel faktörlerden kaynaklı etkileşimler sebebiyle etkisinin azalabilmesidir. Sarımsak ekstraktı in vivo denemelerde hastalığı baskılasa da tohumun çimlenmesine yaptığ olumsuz etkiden dolayı pratikte bu hastalığın mücadelesinde tohuma uygulanması önerilmemiştir. Sarımsak ekstraktının tohuma uygulanması tohum çimlenmesine negatif etki etmesine karşılık, sarımsak ekstraktının yeşil aksama uygulanması hastalık oluşumunu önemli derecede baskı altına aldığı yapılan çalışmalarla ortaya konmuştur (Mirik ve Aysan, 2005). Bu özelliği sayesinde bakteriyel hastalıkların mücadelesinde yeşil aksam uygulaması olarak sarımsak ekstraklarının kullanımı önerilmektedir.

Yapılan bu çalışmada Cistus creticus ekstraktı saksı denemesinde hastalığı istatistiki olarak engelleyemezken tarla denemesinde hastalığı \%76 oranında baskılamıştır. Tarla denemesinde hastalığın baskı altına alınmasında ekolojik parametrelerin (sıcaklık, gece gündüz sıcaklık farkı gibi) Cistus creticus ekstraktının etkinliğini artırmış olabilceği öngörülmektedir. Allium sativum ekstraktının aksine Cistus creticus ekstraktı tohuma uygulandığında çimlenmeye herhangi bir olumsuz etkisi tespit edilmemiştir. Fas’ta yetişen Cistus türünden dört farklı bitki ekstraktının domates patojeni Clavibacter michiganensis subsp. michiganensis'e antibakteriyel etkisi de kanıtlanmıştır (Talibi ve ark, 2011). Cistus creticus ekstraktı sadece bakteriyel hastalıklara değil hasat sonu fungal hastalıklardan turunçgillerde acı çürüklük etmeni Geotrichum citri-aurantii’nin mücadelesinde de başarı göstermiştir (Karim ve ark, 2017). Akdeniz ülkelerine özgü olan Cistus türlerinin kimyasal kompozisyonu araştırıldığında ana bileşenin carvacrol olduğu (Hutschenreuther ve ark, 2010) bunun \%36's1 $\alpha$-pinene, \%12'si camphene, \%9'u fenchone, \%9'u bornyl acetate \%8'i viridiflorol ve \%26'sının diğer bileşenlerden oluştuğu (Vieira ve ark, 2017) saptanmıştır. Carvacrol bileşenin içeriğinde yer alan $\alpha$-pinene'nin antibakteriyel etkisinin araştırıldığı bir çalışmada, gram pozitif (S. epidermidis, S. aureus, B. subtilis) ve gram negatif (P. vulgaris, P. aeruginosa, E. coli) bakterilere karşı antibakteriyel etki saptanmış ve $\alpha$-pinene ilk 8 saat içerisinde bakteri gelişimi inhibe ettiği belirtilmiştir (Jiang ve ark, 2011).

Çalışmada en başarılı bitki ekstraktı olarak saptanan Syzygium aromaticum ekstraktının bezelye tohumlarına uygulanması, tohum kökenli enfeksiyonu saksı denemesinde \%95, tarla denemesinde \%98 oranında baskılamıştır. Bu uygulama tohumun çimlenme yeteneğinde herhangi bir azalışa neden olmadığı gibi \%5 artışa neden olmuştur. Kimyasal yapısının \%83'ünün eugenol ve \%9'unun eugenyl acetate olduğu Syzygium aromaticum ekstrakt1, çeltikte hasat sonu fungal hastalık etmenleri Alternaria, Penicillium ve Fusarium türlerine (Pilar Santamarina ve ark, 2016), kakao bitkisinde patojen olan fungal etmen Phytohthora megakarya'ya (Nana ve ark, 2015), sorgum ve misirda patojen olan fungal etmen Aspergillus türlerine (Satish ve ark, 2007) antifungal özellikte olduğu bilinmektedir. Ayrıca Syzygium aromaticum ekstraktının Bradysia procera (Ginseng kök mantar sivrisineği)'ya karşı ovisidal ve larvisidal aktivitesinin de olduğu yakın zamanda yapılan bir çalışmayla kanıtlanmıştır (Hong ve ark, 2018). Syzygium aromaticum'un etken maddesi olan eugenol'un diş eti iltihabına neden olan patojenik bakteri Porphyromonas gingivalis'e karşı antibakteriyel ve antibiofilm aktivitesi olduğu belirlenmiştir. Ağız ve diş sağlı̆̆ için bakteri plaklarının önlenmesinde eugenol'un sakıza ve/veya diş macununa eklenmesi önerilmiştir (Zhang ve ark, 2017). 
Bitki dayanıklılık mekanizmalarının çeşitli biyotik ve abiotik faktörlerle uyarılması sonucunda sistemik olarak harekete geçirilmesiyle oluşan ve sistemik kazanılmış dayanıklılık (sistemic acquired resistance=SAR) olarak adlandırılan yaklaşım bitki hastalık ve zararlılarla mücadele önem kazanmaktadır. Bitki dayanıklılığını sistemik olarak uyaran bileşikler; toksikolojik açıdan güvenli, çok düşük miktarlarda uygulanabilen, patojenlere doğrudan etki yapmadıklarından dayanıklı ırk oluşturmayan, çok sayıda hastalık ve zararlıya etkili olabilen kimyasallardır. Ayrıca çok sayıda patojene karşı etkili olabildiklerinden entegre programlarında alternatif olarak kullanılabilmektedir (Baysal ve ark, 2003). Birçok doğal ve sentetik olarak üretilmiş kimsayallar bitkilerde bulunan kazanılmış dayanıklılık mekanizmasını teşvik etmektedir (Kessmann ve ark, 1994). Bitki patojenlerine karşı sistemik kazanılmış dayanıklığı teşvik etmek amacıyla; harpin proteini (Akbudak ve Tezcan, 2006), salisilik asit (Kessmann ve ark, 1994), avirülent patojenler, zayıflatılmış veya öldürülmüş patojenler ve patojenin hücre duvar bileşenleri (Dolar, 2011) gibi uyarıcılar kullanılabilmektedir. Bu çalışmada araştırılan farklı bitki türlerine ait ekstraktlar doğal biyokimyasallar içermektedir. Bu biyokimsallar hem antibakteriyel etki ile hem de SAR mekanizmalarını uyararak Pseudomonas pisi'ye karşı engelleyici etkide bulunmuş olabilir. Ekstraktların in vitro, sera ve arazi koşullarında farklı oranlarda antibakteriyel etki göstermelerinin bir sebebi de, bu biyokimyasalların çevre koşullarına bağlı olarak SAR mekanizmalarını uyarması ve buna bağlı olarak farklı oranlarda hastalık oluşturmasıdır.

Bitki ekstraktlarının elde edilmesinde farklı ekstraksiyon yöntemleri (Dekoksiyon, infüzyon, su buharı destilasyonu vb.) uygulanmaktadır. Bu yöntemlerde kullanılan çözücüler ve uygulama sırasındaki sıcaklık farklılıkları elde edilen bitki ekstraktların biyokimyasal içeriğinde ve yoğunluğunda farklılıklar maydana getirebilmektedir. Sarımsak ekstraktının domates bakteriyel leke hastalığına in vitro da antibakteriyel etkisi bulunurken, otoklavdan geçirilmiş aynı yoğunluktaki sarımsak ekstraktının antibakteriyel etkisini kaybettiği belirtilmiştir. Bu değişimin sebebi olarak, ekstraktın yüksek sıcaklık ve basınç altında biyokimyasal yapısının değişmesinden kaynaknaklanabileceği bildirilmiş̧tir (Mirik ve Aysan, 2005). Bu bağlamda sıcaklık, fiziksel uygulamalar ve çözücüler gibi faktörlere bağlı olarak değişiklik gösteren yöntemlerde bitki ekstraktlarının antibakteriyel özelliğinin değişmesi mümküdür. Bu sebeple farklı ekstraksiyon yöntemleri kullanılarak ilgili bitki türü için antibakteriyel etki açısından en başarılı yöntem seçilerek ekstraksiyon yapılmalıdır. Bu sayede antibakteriyel etkisi olmadığı düşünülen bitki türlerinin farklı yöntemler kullanılarak elde edilen ekstrakları ile yapılan testlerde pozitif sonuç alınabilir.

Tarımsal üretimdeki yoğun pestisit kullanımıyla tahrip edilen ekolojik düzen sadece insan sağlığını değil, ekolojik sistem içerisinde yer alan her türlü canlı ve cansız birçok doğa unsurunu olumsuz yönde etkilemektedir. $\mathrm{Bu}$ nedenle doğanın bize sunduğu zenginliklerden faydalanarak sorunlara çevreci çözümler üretmekle doğayı koruyarak tarımsal üretim gerçekleştirmekde mümkündür. Yapılan bu çalışmada da görüldüğü gibi bitki hastalıklarının mücadelesinde çevre dostu yöntemlerin entegre mücadeleye dahil edilmesi son derece önemlidir. Bu bağlamda çalışmalarımızdan elde ettiğimiz sonuçlar çerçevesinde bezelye tarımında önemli bir sorun olarak karşımıza çıkan yaprak yanıklığı hastalığı ile mücadelede Syzygium aromaticum ekstraktının tohuma uygulanması paratik ve etkili bir çözüm olarak ekonomik anlamda bitki korumaya katkı sağlamıştır. 


\section{Sonuc}

Pseudomoas syringae pv. pisi adlı bakteriyel etmenin neden olduğu bezelye bakteriyel yaprak yanıklık hastalığı, dünya genelinde bezelye tarımının yapıldığı alanlarda bitki sağlığını olumsuz yönde etkileyerek verim kayıplarına neden olan önemli bir problemdir. Tohumla taşınan bakteriyel bir patojen olan etmenin en önemli inokulum kaynağı patojenle bulaşık tohumlardır. Bu nedenle ekim sonrası yapılan bitki koruma uygulamaları hastalıkla mücadelede istenilen sonuca ulaşmakta yetersiz kalmaktadır. İlk inokulum kaynağı olan tohumlardan patojenin uzaklaştırılması hastalıkla mücadelede yüksek etkili, pratik ve ekonomik bir çözüm olmaktadır.

Bu çalışma, Pseudomonas syringae pv. pisi’ye karşı antibakteriyel özeliğe sahip bitki ekstraktlarının tespit edilmesi, tohum uygulaması olarak kullanıldığında hastalığı baskılama oranının belirlenmesi ve uygulamaların tohumların çimlenme yeteneğine etkisinin belirlenmesi amacıyla gerçekleştirilmiştir. Seralarda yapılan saksı denemesinde patojenle bulaşık bezelye tohumlarına Cistus creticus ekstraktı uygulandığında bitkilerin \%51'inde, Allium sativum ekstraktı uygulandığında bitkilerin \%33'ünde ve Syzygium aromaticum ekstraktı uygulandığında bitkilerin \%3'ünde hastalık saptanmıştır. Bitkinin doğal ortamında hastalık çıkışının belirlenmesi için yaptığımız tarla denemelerinde patojenle bulaşık bezelye tohumlarına $C$. creticus ekstraktı uygulandığında bitkilerin \%12'inde, Allium sativum ekstraktı uygulandığında bitkilerin \%8'inde hastalık saptanmıştır. S. aromaticum ekstraktı uygulanan tohumlardan gelişen bitkilerin \%1'inde hastalık saptanmıştır. Ayrıca uygulamaların tohum fizyolojisine etkisi sonucu tohumların çimlenme yeteneğindeki değişimi belirlemek amacıyla yaptığımız denemelerde sağlıklı tohumlar A. sativum'un sulu ekstraktına daldırıldığında tohumların \%78'i çimlenmiştir. $\mathrm{Bu}$ uygulama tohumların çimlenme oranını \%18 düzeyinde azaltmıştır. C. creticus ekstraktıyla uygulama görmüş tohumların \%93'ü çimlenmiş ve çimlenme \%3 oranında azalmıştır. Bunların aksine sağlıklı tohumlara S. aromaticum'un sulu ekstraktı uygulandığında tohumların çimlenme oranında \% $\%$ 'lik artış saptanmıştır.

Tüm bu veriler göz önüne alındığında bezelye bakteriyel yaprak yanıklık hastalığının mücadelesi kapsamında uygulanacak en etkili ve doğal yöntem, Syzygium aromaticum (Baharat Karanfil) ekstraktının ekim öncesi tohum uygulaması şeklinde kullanılmasıdır. S. aromaticum ekstraktının tohuma uygulanması pratik ve ucuz olması, doğal ve çevreci bir çözüm olması, tohum çimlenmesine olumlu etkisi ve patojene karşı yüksek etkinliği nedeniyle bezelye tarımının yapıldığı alanlarda uygulanabilir bir yöntemdir. Ayrıca gelecekte bu bitkinin etken maddesi (eugenol) sentetik olarak üretilip hastalık mücadelesinde kullanılabilir. 


\section{Kaynakça/References}

Akbudak, N., Tezcan, H., 2006. Bitkisel üretimde ve bitki korumada yeni bir etken madde: Harpin. Uludağ Üniversitesi Ziraat Fakültesi Dergisi, 20(2), 39-43.

Akça, A., 2016. Farklı yerel bezelye (Pisum sativum L.) hatlarının bakteriyel yanıklık hastalığına reaksiyonu. Çukurova Üniversitesi, Fen Bilimleri Enstitüsü, (Yüksek Lisans Tezi) Sayfa 74.

Altundağ, Ş., 2007. Labiatae familyasına ait bazı endemik türlerin önemli bitki patojeni bakteriler üzerine antimikrobiyal etkisinin araştırılması. Gazi Üniversitesi, Biyoloji Bölümü, (Yüksek Lisans Tezi) Sayfa 85.

Aysan, Y., 2008 Bezelye'de bakteriyel yanıklık hastalığı. Bitki Bakteri Hastalıkları (Editörler H. Saygılı, F. Şahin, Y. Aysan) 109-11. Meta Basim İzmir Sayfa 317.

Bajpai, V.K., Kang, S., Xu, H., Lee, S., Baek, K., Knag, S.C., 2011. Potential roles of essential oil on controlling plant pathogenic bacteria Xanthomonas species: A Review. The Plant Pathology Journal, 27(3): 207-224.

Balestra, G.M., Heydarı, A., Ceccarellı, D., Ovıd1, E., Quattrucc1, A., 2009. Antibacterial effect of Allium sativum and Ficus carica extracts on tomato bacterial pathogens. Crop Protection, 28: 807-811.

Baydar, H., 2009. Sekonder metabolitlerin önemi. Tıbbi ve Aromatik Bitkiler Bilimi ve Teknolojisi. Süleyman Demirel Üniversitesi Yayın No:51 Ziraat Fakültesi. DÜ Basım Evi. Isparta. S: 45-63.

Baysal, Ö., Gürsoy, Y. Z., 2003. Dayanıklılık Artırıcı Bitki Aktivatörü Acibenzolar-S-methyl (ASM)'in Domates Hastalık ve Zararlılarıyla Savaşımda Kullanım Olanakları. alatarım, 27.

Benlioglu, K., Özyilmaz, Ü., Ertan, D. 2010. First report of bacterial blight caused by Pseudomonas syringae pv. pisi on pea in Turkey. Plant Disease, 94: 923

Cantore, P., Shanmugaiah, V., Iacobellis, S., 2009. Antibacterial activity of essential oil components and their potential use in seed disinfection. Agricultural and Food Chemistry, 57: 9454-9461.

Ceyhan, E., Avcı, M., Mcphee, K., 2005. Konya ekolojik şartlarında kışlık olarak yetiștirilen bezelye genotiplerinin verim ve bazı tarımsal özellikleri. S.Ü. Ziraat Fakültesi Dergisi 19 (37): 6-12

Curtis, H., Noll, U., Störmann, J., Slusanrenko, A.J., 2004. Broad-spectrum activity of the volatile phytoanticipin allicin in extracts of garlic (Allium sativum L.) against plant pathogenic bacteria, fungi, and Oomycetes. Physiological and Molecular Plant Pathology, 65: 79-89.

Dolar, S., 2011 (Editör). Fitopatoloji. T.C. Anadolu Üniversitesi Yayınevi No 2293, Açıköğretim Fakültesi Yayını No: 1290, Yazarlar (Sara Dolar, Erkol Demirci, Hüseyin Basım, Fikret Demirci, İ. Özer Elibüyük), 199 sayfa.

El-astal, Z., 2004. The inhibitory action of aqueous garlic extract on the growth of certain pathogenic bacteria. European Journal of Plant Pathology, 218: 460-464.

Ertan, D., 2012. Aydın ve İzmir illeri bezelye üretim alanlarında görülen bakteriyel hastalıkların saptanması. Adnan Menderes Üniversitesi, Fen Bilimleri Enstitüsü, Bitki Koruma Anabilim Dalı (Yüksek Lisans Tezi) Sayfa 89.

Gahukar, R.T., 2012. Evaluation of plant-derived products against pest and diseases of medicinal plants: a review. Crop Production, 42: 202209.

Göre, E., 2003. Bezelye'de Ascochyta hastalıklarıyla biyolojik mücadelede fluoresent Psedudomonas 'ların etkisinin saptanması üzerinde araştırmalar. Ege Üniversitesi, Fen Bilimleri Enstitüsü, Bitki Koruma Anabilim Dalı (Doktora Tezi) Sayfa 172.

Gritton, E.T., 1980. Field Pea. In: hybridization of crop plants (Fehr. W.R. And Hadley. H.H.. Eds.). American Society of Agronomy. Inc; And Crop Science Society of America. Inc; Pp.347-356. Wisconsin, USA.

Hong, T., Perumalsamy, H., Jang, K., Na, E., 2018. Ovicidal and larvicidal activity and possible mode of action of phenylpropanoids and ketone 1dentified in Syzygium aromaticum bug against Bradysia procera. Pesticide Biochemistry and Physiology, 145: 29-38.

Horuz, S., Koksal-Akca, A., Gunes, M., Aktepe, B.P., And Aysan, Y., 2015. Occurrence of pea bacterial blight caused by Psedomonas syringae pv. pisi in the eastern mediterranean region of Turkey. 18. International Plant Protection Congress 24-27 August 2015. Berlin. Germany. Abstracts Book Page 741 .

Hutschenreuther, A., Birkemeyer, C., Grötringer, K., Straubinger, R.K., Rauwaldi, H.W., 2010. Growth inhibiting activity of volatile oil from Cistus creticus L. against Borrelia burgdorferi s.s. In vitro. Pharmazie, 65:290-295.

Jiang, Y., Wu, N., Fu, Y. J., Wang, W., Luo, M., Zhao, C. J., Liu, X. L. (2011). Chemical composition and antimicrobial activity of the essential oil of Rosemary. Environmental toxicology and pharmacology, 32(1), 63-68.

Kagale, S., Marimuthu, T., Thayyumanavan, B., Nandakurmar, R., Samiyappan, R., 2004. Antimicrobial activity and induction of systemic resistance in rice by leaf extrackt of Datura metel against Rhizoctonia Solani and Xanthomonas oryzae pv. oryzae. Physiological and Moleculer Plant Pathology, 65:91-100.

Karabuyuk, F., Aysan, Y., 2016. Aqueous plant extracts as seed treatments on tomato bacterial speck disease. 5 Th International Symposium on Tomato Diseases. Malaga. Spain,June 13-16. 2016. Page 96. 
Umarusman \& Aysan \& Özgüven

Farklı Bitki Ekstraktlarının Bezelye Bakteriyel Yaprak Yanıklığına (Pseudomonas syringae pv. pisi) Antibakteriyel Etkilerinin Araştırılması

Karim, H., Boubaker, H., Askarne, L., Cherifi, K., Lakhtar, H., Msanda, F., Boudyach, E.H., Aoumr, A., 2017. Use of cistus aqueous extracts as botanical fungicides in control of citrus sour rot. Microbial Pathogenesis, 104: 263-267.

Kessmann, H., Staub, T., Hofmann, C., Maetzke, T., Herzog, J., Ward, E., Ryals, J., 1994. Induction of systemic acquired disease resistance in plants by chemicals. Annual review of phytopathology, 32(1), 439-459.

Kotan, R., Cakir, A., Dadasoglu, F., Aydin, T., Cakmakci, R., Ozer, H., Kordali, S., Mete, E., Dikbas, N., 2009. Antibacterial activities of essential oils and extracts of Turkish Achillea, Satureja and Thymus species against plant pathogenic bacteria. Society of Chemical Industry, 90: 145-160.

Kotan, R., Kordalı, S., Cakır, A., 2007. Screening of antibacterial activities of twenty-one oxygenated monoterpenes. Verlag der Zeitschrift für Naturforschung, 62:7-8.

Lelliott, R.A., Stead, D.E., 1987. Methods for the diagnosis of bacterial diseases of plants. Methods in Plant Pathology Volume 2 (Series editor T. F. Preece). Published on behalf of the British Society for Plant Pathology by Blackwell Scientific Publications. Oxford. UK. 219 pages.

Mangamma, P., A. Speeramula, 1981. Garlic extract inhibitory to growth of Xanthomonas campetris pv. vesicatoria. Indian Phytopathology, 44:372.

Martin-Sanz, A., Garcia Vaquero, C.A., Caminero Saldana, C. 2005. Pea bacterial blight: A problem in Castilla y León. Grain Legumes, 41: 8-9.

Mbega, E.R., Mortensen, C.N., Mabagala, R.B., Wulff, E.G., 2012. The effect of plant extracts as seed treatments to control bacterial leaf of tomato in Tanzania. Journal of General Plant Pathology, 78: 277-286.

Mirik, M., Aysan, Y., 2005. Effect of some plant extracts as seed treatment on bacterial spot disease of tomato and pepper. The Journal of Turkish Phytopathology, 34(1-3): 9-16.

Nana, W., Eke, P., Fokom, R., Bakanrga-Via, I., Begoude, D., Tchana, T., Tchameni, N., Kuate, J., Menut, C., Boyom, F., 2015. Antimicrobial activity of Syzygium aromaticum and Zanthoxylum xanthoxyloides essential oil against Phytophthora megakarya. Journal Phytopathology, 163: 632-641.

Parry, D.W. 1990. Plant pathology in agriculture. Cambridge University Press, Cambridge.

Pilar Santamarina, M., Rosello, J., Gimenez, S., Blazques, M., 2016. Commercial Laurus nobilis L. and Syzygium aromaticum L. Merr. \& Perry essential oils against post-harvest phytopathogenic fungi on rice. Food Science and Technology, 65: 325-332.

Reeves, J.C., Hutchins, J.D., Simpkins, S.A. 1996. The incidence of races of Pseudomonas syringae pv. pisi in UK pea (Pisum sativum) seed stocks, 1987-1994. Plant Varieties and Seeds, 9: 1-8.

Satish, S., Mohana, D.C., Raghavendra, M.P., Raveesha, K.A., 2007. Antifungal activity of some plant extracts against important seed-borne pathogens of Aspergillus sp.. Journal of Agricultural Technology, 3: 109-119.

Satish, S., Raveesha, K.A., Janardhana, G.R., 1998. Antibacterial activity of plant extracts on phytopathogenic Xanthomonas campestris pathovars. Letters in Applied Microbiology, 28: 145-147.

Savoia, D., 2011. Plant-derived antimicrobial compounds: alternatives to antibiotics. Future Microbilogy, 7(8): 979-990.

Slusarenko, A.J., Patel, A., Ports, D., 2008. Control of plant diseases by natural products: allicin from garlic as a case study. European Journal of Plant Pathology, 121: 313-322.

Talibi, I., Amkraz, N., Askarne, L., Msanda, F., Saadi, B., Boudyach, E.H., Boubaker, H., Bouizgarne, B., Ait Ben aoumar, A., 2011. Antibacterial activity of Moroccan plants extracts against Clavibacter michiganensis subsp. michiganensis, the causal agant of tomatoes bacterial canker. Journal of Medicinal Plants Research, 5: 4332-4338.

Taylor, J.D., Dye, D.W., 1975. Evaluation of streptomycin seed treatments for control of bacterial blight of peas (Pseudomonas pisi Sackett 1916). Journal of Agricultureal Research, 19: 91-95.

Topal, M., Şenel, G., Topal, E., Öbek, E., 2015. Antibiyotikler ve kullanım alanları. Erciyes Üniversitesi, Fen Bilimleri Enstitüsü Dergisi, 31(3):121-127

Verma, K.A., Agrawal, K., 2017. In vitro evaluation of antibacterial activity of some medicinal plants against Xanthomonas pisi causing leaf spot of pea. International Journal of Pharmaceutical Sciences Review and Research, 29: 156-159.

Verma. K.A.. Agrawal. K.. 2015. B10-efficacy of some medicinal plant extracts against Pseudomonas syringae pv. pisi causing bacterial blight of pea. International Journal of Pharmacology and Toxicology, 5(1): 67-70.

Vieira, M., Bessa, L.J., Matins, M.R., Arentes, S., Teixeria, A.P.S., Mendes, A., Costa, P.M., Belo, A.D.F., 2017. Chemical composition, antibacterial, antibiofilm and synergistic properties of essential oil from Eucalyptus globulus Labill. and seven Mediterranean aromatic plants. Chemistry and Biodiversity, 6: 1-12.

Zhang, Y., Wang, Y., Zhu, X., Cao, P., Wei, S., Lu, Y., 2017. Antibacterial and antibiofilm activities of eugenol from essential oil of Syzygium aromaticum (L.) Merr \& L. M. Perry (clove) leaf against peridontal pathogen Porhyromonas gingivalis. Microbial Pathogenesis, 113: 396402. 